HISTORY OF MEDICINE

\title{
The Worshipful Society of Apothecaries of London
}

\author{
P Hunting
}

Postgrad Med J 2004;80:41-44. doi: 10.1136/pgmj.2003.015933

The Society of Apothecaries is both a City livery company and an examining authority for the medical profession. Founded in 1617 by the royal apothecary Gideon de Laune leading a breakaway group from the Grocers' Company, the Society was instrumental in raising the status of apothecaries as general practitioners. Under the Apothecaries' Act (1815) the Society examined for the LSA and it now awards the LMSSA (Licence in Medicine and Surgery of the Society of Apothecaries) and postgraduate diplomas, while maintaining the civic, charitable, and ceremonial traditions of a livery company of the City of London.

Correspondence to:

Dr Penelope Hunting, 40 Smith Street, London SW3 4EP, UK; penelope@ reformed.demon.co.uk

Submitted 15October 2003 Accepted 15 October 2003
$\mathrm{T}$ he skill of the medieval apothecary lay in his knowledge of plants, his ability to compound and dispense medicines and remedies, his willingness to treat the sick poor and to perform basic surgery. Nothing if not versatile, the apothecary was the physician's cook, the community's general practitioner, and the local pharmacist whose shop was a storehouse of pungent powders, fragrant herbs, and contorted roots. Jars of mysterious drugs and syrups lined the shelves, jostling for space with dried animal skins and seeds; perhaps a stuffed alligator or a desiccated tortoise hung from the ceiling.

The spicers, pepperers, and apothecaries of medieval London fell under the jurisdiction of the powerful Grocers' Company. As their prosperity increased apothecaries came to resent the restrictions, discipline, and shop searches imposed by the Grocers; they desired independence and the control of their own affairs. The poor laws of the Elizabethan era had the effect of enhancing the role of apothecaries who became largely responsible for the medical care of the sick poor. Their heightened profile prompted a petition to secure the monopoly of compounding and selling medicines for apothecaries, but the timing was not propitious (this was 1588-the year of the Spanish Armada). The conclusion of war with Spain, the accession to the throne of the amenable King James I, and the emergence of the royal apothecary Gideon de Laune provided more favourable circumstances, leading to the founding of the Society of Apothecaries in 1617.

\section{GIDEON DE LAUNE}

The 8 year old Gideon de Laune came to London with his family in 1573. They were Huguenot refugees who settled at Black Friars, within the precinct of the former Dominican Priory. Gideon's father was a physician but Gideon chose to practise as an apothecary from a shop at Black Friars, making his name and fortune from the manufacture of De Laune's Pills, a nostrum recommended for scurvy, dropsy, jaundice, venereal disease, worms, etc. De Laune did not join the Grocers' Company and he was prepared to defy that Company's authority by leading a breakaway group of apothecaries determined to establish their independence. There was an acrimonious confrontation between de Laune and the Court of the Grocers' Company in 1610 when the apothecaries' bid for self regulation failed. By 1614 however, de Laune had recruited the support of a fellow Huguenot, the King's physician Dr Theodore Mayerne, and Dr Henry Atkins, seven times President of the College of Physicians who was likewise favoured by the King. De Laune's own standing as apothecary to Queen Anne doubtless helped his cause and the apothecaries' petition for a royal charter met with success. Letters Patent granted by King James in December 1617 named the 122 founder members of the Society of Apothecaries.

The new Society was a self governing corporation dedicated to training apprentices in the art of the apothecary, ensuring that medicines made and sold by its members were genuine, punishing frauds, and raising standards of practice among London apothecaries generally-to the benefit of the general public, particularly those who could not afford to consult a physician.

The wealthy and influential de Laune was not only the founder of the Society, he was also its chief benefactor. As the Court of Assistants acknowledged, he was "a principal means for the procuring of the said Company to be made a corporation and for the purchasing of the capital messuage now belonging to the said Company called Apothecaries' Hall". ${ }^{2}$ He presented two cups to the Society, and his portrait, which hangs at the Hall (see fig 1) where he is also commemorated in a marble bust.

\section{THE 17TH CENTURY SOCIETY}

During the course of the 17th century the Society of Apothecaries established its Hall within the precinct of the former Black Friars Priory, founded the Physic Garden at Chelsea, commissioned a ceremonial barge, and took its place as 58th in the order of precedence of the City livery companies.

The regulation of the trade of London apothecaries entailed the inspection of apothecaries' shops when any rotten goods would be confiscated, malpractice was punished, and disputes between members were settled. It was also important that apothecaries' apprentices were trained to the required standard during a seven or eight year apprenticeship. Their education 


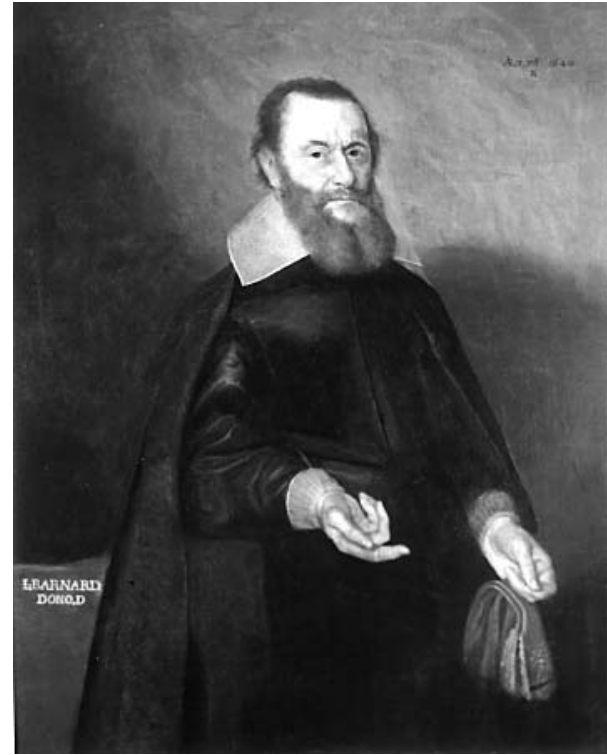

Figure 1 Gideon de Laune (1565-1659) from a painting by Cornelis Jonson van Ceulen. Founder, benefactor and twice Master, de Laune presented his portrait to the Society in 1642.

included instruction in chemistry and botany: the Society's Chemical Operator was responsible for teaching his subject, while the Botanical Demonstrator taught the apprentices which plants were used in physic by demonstrating them at the Chelsea Physic Garden and on herbarizings. It was vital that apothecaries were familiar with the therapeutic properties and uses of the plants, herbs, roots, fruits, and barks that were the primary source of medicines and salves, so apprentices were taken on herbarizing expeditions to Fulham, Greenwich, and other open spaces where plants were collected and studied. These summer herbarizings were one of the Society's core activities and they set the example for field trips which are still essential to the study of natural history, geography, and botany today. While the apprentices (sustained by bread and ale) were instructed at private herbarizings, more sophisticated general herbarizings were held for the senior fraternity, to which eminent guests such as Sir Hans Sloane were invited, and the day culminated in a dinner-at The Bowling Green in Putney, for instance.

As the Society of Apothecaries grew in numbers and stature, conflict with the College of Physicians became inevitable. Physicians of the College were an elite and generally they regarded apothecaries as their inferiors; moreover apothecaries tended to undermine the physicians' authority and deprive them of fees. Rivalry between the College and the Society was a recurring theme until the apothecaries scored a victory in 1704 when the case of William Rose, an apothecary prosecuted for not only prescribing and dispensing medicines but also for visiting a patient, was taken to the House of Lords. Judgment was given in Rose's favour, thereby giving legal recognition to the apothecary as a general practitioner.

Apothecaries were further encouraged when Sloane, Lord of the Manor of Chelsea, conveyed the Physic Garden to the Society on favourable terms. The agreement of 1722 stimulated a period of horticultural activity, building, and renovation at the Physic Garden which, under the Directorship of Isaac Rand and with Philip Miller as gardener, achieved international renown. ${ }^{3}$ The Chelsea Physic Garden continues to flourish as a haven where medicinal plants are cultivated for the purpose of research and education. It is now an independent charity with a representative of the Society of Apothecaries on the Board of Trustees.

\section{TRADING ACTIVITIES}

The City livery companies were founded on the trades and crafts of London and the apothecaries were particularly well placed to exploit the demands of an increasing population for drugs, medicines, potions, and pharmaceutical remedies. Demand was such that in 1672 the Society built a laboratory at Apothecaries' Hall where herbs grown at the Physic Garden were processed and chemical preparations manufactured (see fig 2). These operations were under the management of the Laboratory Stock, a stock company that ensured the medicines and drugs manufactured and sold at the Hall were of good quality. The trade expanded to supply the army, navy and the colonies, prompting the formation of the Navy Stock in 1703. By the close of the 18th century medicine chests from Apothecaries' Hall, complete with the requisite pills, mixtures and basic instruments, were essential equipment for naval surgeons and explorers: Captain Cook's voyages of discovery and convict fleets sailing to Australia had the benefit of medicines and supplies obtained from the Society of Apothecaries.

The two stock companies combined their activities in 1822 after the acquisition of an old foundry behind Apothecaries' Hall where the industrial processes centred on the chemical laboratory, the still house, and a magnesia room where furnaces, vats, and stoves throbbed and bubbled under the surveillance of the Chemical Operator. The processes were not without risk and on one occasion a series of explosions ripped apart the body of Henry Hennell, sending parts of his anatomy across the street and onto the roof.

Ultimately, the Society could not sustain both its trading and professional interests. By the early 20th century commercial competition in drug manufacturing had stiffened and profits from the manufacture of medicines, pharmaceutical preparations, and surgical appliances at Apothecaries' Hall declined. Employees of the trade department clamoured for pay increases and held a strike, heralding the closure of manufacturing at the Hall in 1922. The retail business, complete with valuable prescription books and formulae were disposed of; likewise the pharmacy at the Hall was dismantled and the utensils, jars, mahogany counters, and cabinets were offered for sale.

\section{APOTHECARIES' HALL}

The Society boasts the oldest surviving livery hall in the City; it is certainly one of the most attractive. Situated in a secluded courtyard on the east side of Black Friars Lane, Apothecaries' Hall is not as grand as Drapers' Hall, nor as palatial as Fishmongers' Hall, but it possesses a special charm and intimacy (see fig 3).

With the help of Gideon de Laune the Society purchased the mansion called Cobham House for its Hall in 1632-Lord Cobham had acquired the former guest house of Black Friars Priory after the dissolution of the friary in 1538. The property extended south to the River Thames where the Apothecaries had access to their barge and thence to the Chelsea Physic Garden, to a herbarizing, or to participate in the ceremonial procession of state barges on Lord Mayor's Day.

The Hall survived the vicissitudes of the civil war and interregnum but was destroyed in the Great Fire of September 1666. Thomas Lock was responsible for rebuilding on the old foundations (1668-70) and his work survives: the Great Hall (see fig 4), Parlour, Court Room, and carved staircase are recognised as some of the finest late 17th century interiors of any livery hall. ${ }^{4}$ While the main reception rooms of the post-Fire Hall have been preserved, the street frontage was rebuilt by the surveyor Richard Norris in the 1780s to provide larger premises for the Society's trading activities, with access to the courtyard and Hall through a central archway. Thus the west and south elevations facing 


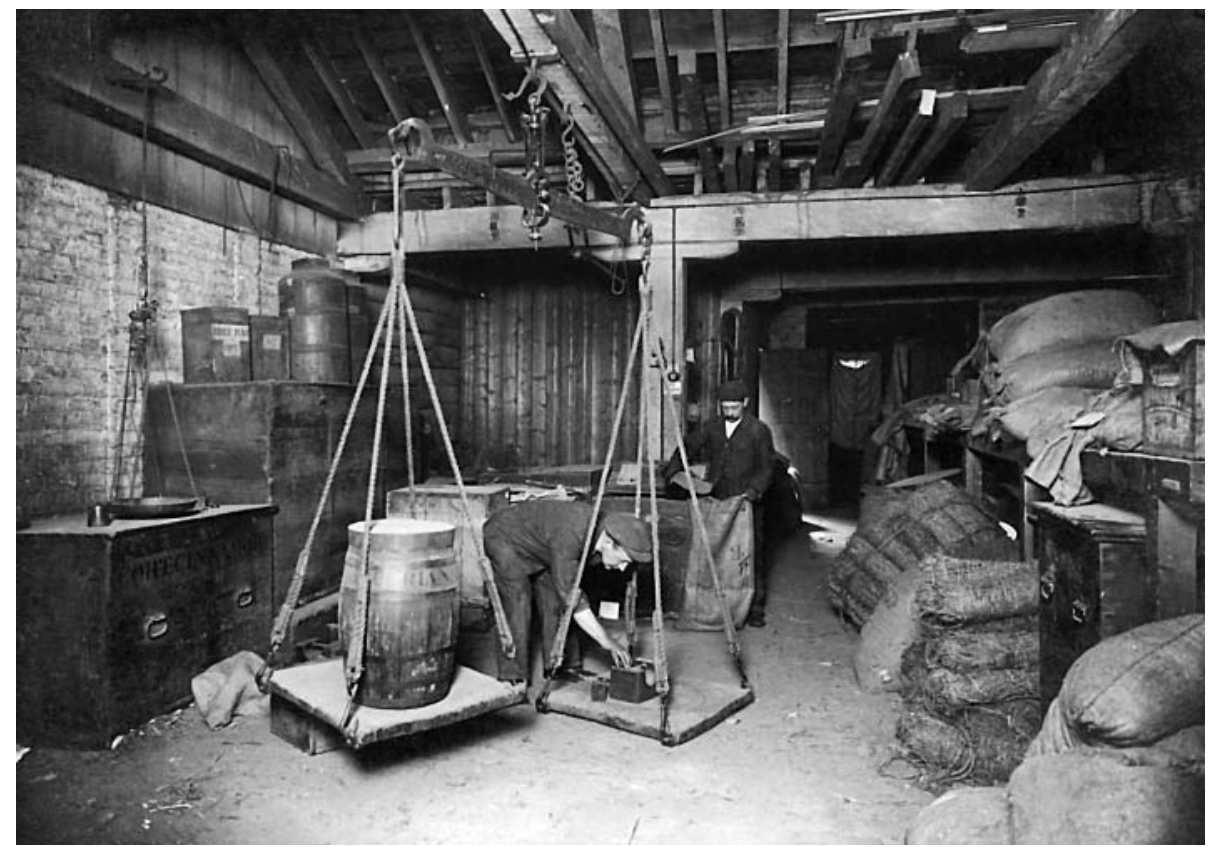

Figure 2 The manufacture of drugs and medicines at Apothecaries' Hall was a major activity until the closure of the trade in 1922.

Black Friars Lane and Playhouse Yard were given their sturdy, industrial appearance, whereas the Society's Hall preserves the character of a late 17th century town house.

\section{PROFESSIONAL EXAMINATIONS}

The educational role of the Society expanded when in the early 19th century it became an examining body for the

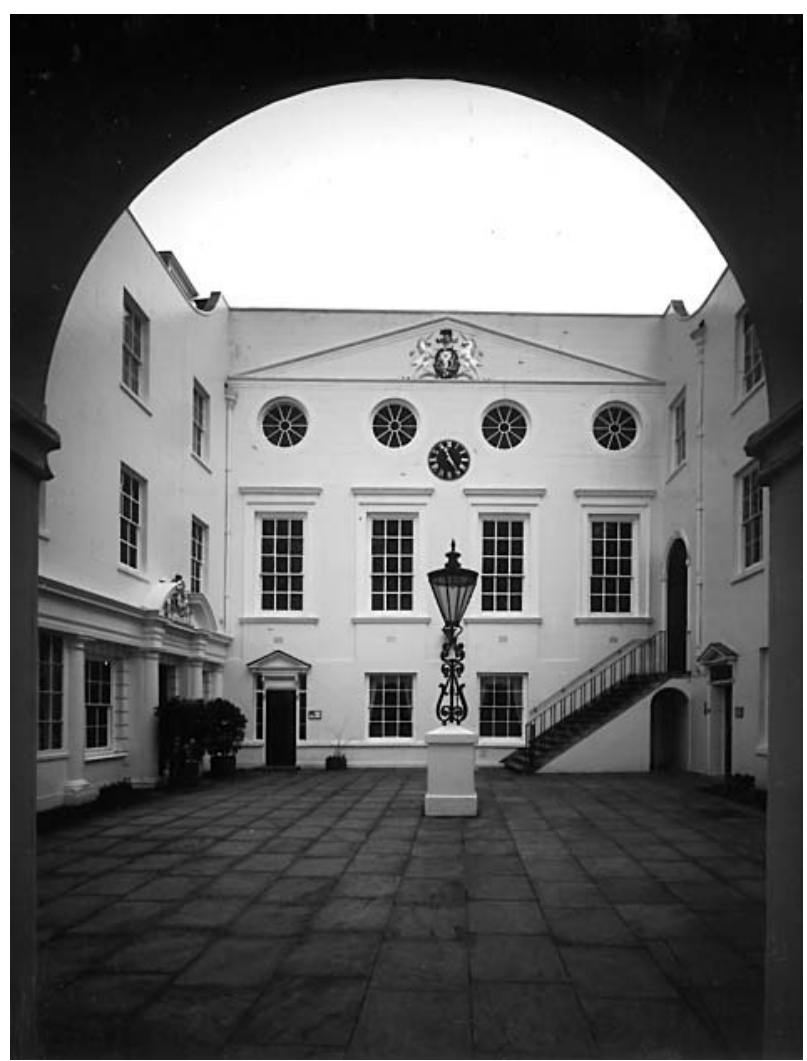

Figure 3 The courtyard of Apothecaries' Hall, Black Friars Lane, London. medical profession. Apprentices had always been subject to examination by their seniors as a condition of being granted freedom to practise and from 1815 the Society's responsibilities were extended to embrace the increasing number of medical students seeking a valid medical qualification. The Apothecaries' Act of 1815 was the first of a series of 19th century reforms aimed at raising standards of medical education and regulating the profession in England and Wales. As an examining authority appointed by Act of Parliament the Society of Apothecaries played an important part in this movement and the LSA (Licenciate of the Society of Apothecaries) became a popular qualification.

One notable candidate who came before the Society's Court of Examiners was John Keats who as number 189 sat for the LSA in 1816, with success. However a few months' experience as a surgeon's dresser proved the limit for Keats and he turned to literary pursuits. Similarly, it was through the portals of Apothecaries' Hall that Elizabeth Garrett Anderson managed to obtain the LSA in 1865-the first woman to do so in Britain. Her achievement paved the way for the foundation of the London School of Medicine for Women in 1874 and the acceptance of women into the medical profession.

The Apothecaries' Act also gave the Society responsibility for examining Apothecaries' Assistants or Dispensers, the majority of whom were women. Among those sitting this examination at the Hall in 1917 was Agatha Christie, then working in the Dispensary of the Red Cross Hospital, Torquay, where she drafted her first detective novel. Her knowledge of drugs, especially poisons, was to serve her well in her subsequent career.

The Society continued to examine Dispensers until 1998 and from 1928 to 1963 it awarded the first postgraduate diplomas in midwifery (the MMSA-Mastery of Midwifery of the Society of Apothecaries). It administered examinations for biophysical assistants in electrotherapeutics (the BPASA), and as the 20th century wore on diplomas were established in industrial health, medical jurisprudence, genitourinary medicine, sports medicine, regulatory toxicology, musculoskeletal medicine, the medical care of catastrophes, and clinical pharmacology. Ultimately, the Mastery of Midwifery led to 


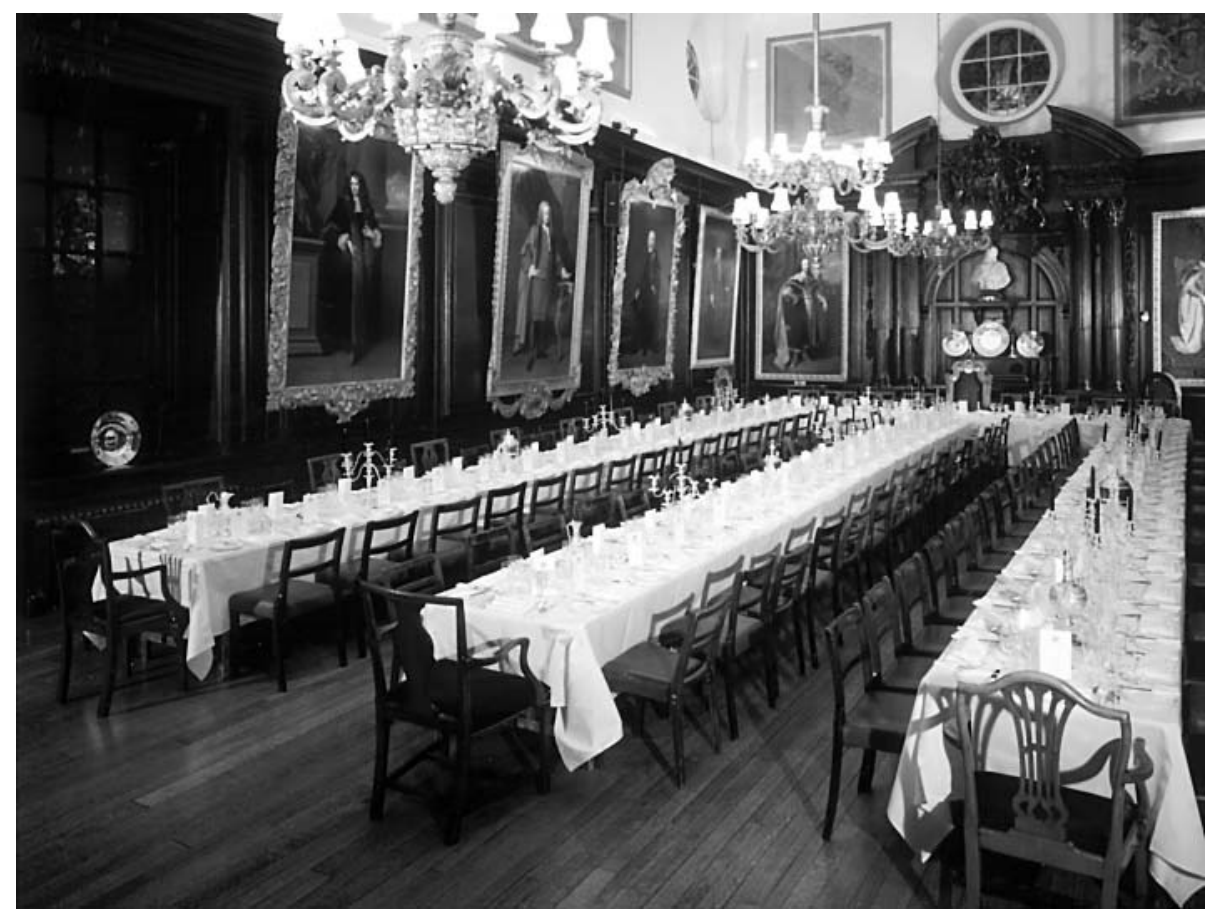

Figure 4 The Great Hall is hung with portraits of King Charles I, King James I, Masters, benefactors, and members of the Society. The marble bust of de Laune by John Young (1676) surveys the scene from the far end.

the founding of the Royal College of Obstetrics and Gynaecology; the Diploma in Industrial Health prompted the formation of the Institute of Occupational Medicine; and several other medical specialties pioneered by the Society of Apothecaries have achieved wider acclaim as Faculties or Sections of the Royal Society of Medicine.

The Faculty of the History and Philosophy of Medicine and Pharmacy, founded at Apothecaries' Hall in 1959, organises lectures, prizes, the appointment of lecturers at medical schools, and courses in medical history for undergraduates. Since 1970 the Faculty has awarded the Diploma in the History of Medicine of the Society of Apothecaries (DHMSA), augmented by the Diploma in the Philosophy of Medicine (DPMSA) from 1978. The Society is the only non-university medical licensing authority in the UK and as a member of the United Examining Board it grants the LMSSA and awards 11 postgraduate diplomas.

A new initiative for the Society celebrates the historic relationship between apothecaries and general practitioners, and commemorates the names of William Rose whose appeal sanctioned the apothecary's right to practise medicine, and Dr Fraser Rose, a co-founder of the Royal College of General Practitioners. The Rose Prize for an original, unpublished dissertation on the History of British General Practice is offered jointly by the Society and the College: the first award will be made in 2005 when the winner will be presented, appropriately, with the Rose Bowl.

\section{A LIVERY COMPANY FOR THE MEDICAL PROFESSION}

The Society of Apothecaries is the preferred livery company of the medical profession and with a total membership of 1747 this is the largest of the 103 City livery companies. Nonmedical membership is limited to $15 \%$, while the Court of Assistants, which forms the governing body of 24 senior members, consists of not less than 22 registered medical practitioners. At the apex of the Society stand the Master and two Wardens who are elected annually on the basis of seniority. The appeal of the Hall where the Society's impressive oil paintings ${ }^{5}$ and valuable collection of antique drug jars are displayed, the traditional livery dinners held in the Great Hall, lectures, and other social occasions make membership of the Society desirable and keenly sought.

In common with other livery companies, the Society of Apothecaries dispenses charity-to widows, distressed members, medical students, schools, and needy institutions; in 1982 a charitable fund was established to focus specifically on grants and donations. In many ways the Society of Apothecaries is an anomaly, combining as it does the duties of a licensing authority for the medical profession with the charitable, ceremonial, and social traditions of a City livery company. In fulfilling this dual role the Society represents the medical profession in the City of London-as it has done for four centuries.

The main source is the author's History of the Society of Apothecaries. London: Society of Apothecaries 1998, available from Apothecaries' Hall, Black Friars Lane, London EC4V 6EJ for £37.50 plus post and packing. For information about the Society's archives contact the Archivist, Ms Dee Cook. The illustrations are reproduced with kind permission of the Society of Apothecaries and the author would like to thank the Clerk and the Archivist for their help.

\section{REFERENCES}

1 Shakespeare W. In Shakespeare's Romeo and Juliet, 1597, Act V scene I, Romeo describes the apothecary's shop in these terms.

2 Society of Apothecaries. Society of Apothecaries' Court minutes. London: 11 July 1648.

3 Hunting P. Isaac Rand and the Apothecaries' Physic Garden. Garden History 2002; spring 30:1-23

4 Bradley S, Pevsner N. The buildings of England. London 1: the City of London. London: Penguin Books, 1997:375.

5 Walters D. A catalogue of selected portraits and pictures at Apothecaries' Hall. London: Society of Apothecaries, 1997. 